\title{
Functioning of Eklavya Model Residential School, Rayagada, Odisha
}

\author{
Sonalika Biswal ${ }^{1}$ and Ashok Dansana ${ }^{2 *}$
}

${ }^{1}$ Faculty of Education, Department of Teacher Education, S.C.S. Autonomous College, Puri, Odisha, India

${ }^{2}$ Assistant Professor, School of Education, Ravenshaw University, Cuttack, Odisha, India

*Corresponding author: dansana.cie@gmail.com

Received: 20-05-2021 Revised: 23-07-2021 Accepted: 12-08-2021

\begin{abstract}
In school, infrastructure development is an important aspect that needs to be taken into account. The term infrastructure is comprehensive, and several elements are included in it. These include playgrounds, library facilities, laboratories, computer centers, technology, machinery, tools, equipment, and so forth. The members of the educational institutions need to invest resources to bring about infrastructure improvements. The study aimed to investigate the current status of the availability and utilization of infrastructure in Eklavya Model Residential School. The investigator purposively selected one Eklavya Model Residential School at Rayagada in Odisha. This school provides quality education to merit-based tribal students, especially in tribal areas. The researcher has followed the purposive sampling technique for selecting the key informants of the case. The researcher used the classroom Observation Schedule, Questionnaire, checklist, and interview schedule for data collection. The data was analyzed by applying both quantitative and qualitative techniques, i.e., percentage; thick description. The study revealed that the infrastructure facilities are available as per the guideline of Eklavya Model Residential School.
\end{abstract}

Keywords: Availability, Utilization, Eklavya Model Residential School

The study aimed to investigate the current status of the availability and utilization of infrastructure in Eklavya Model Residential School. The investigator purposively selected one Eklavya Model Residential School at Rayagada in Odisha. This school provides quality education to merit-based tribal students, especially in tribal areas. The researcher has followed the purposive sampling technique for selecting the key informants of the case. The researcher used the classroom Observation Schedule, Questionnaire, checklist, and interview schedule for data collection. The data was analyzed by applying both quantitative and qualitative techniques, i.e., percentage; thick description. The study revealed that the infrastructure facilities are available as per the guideline of Eklavya Model Residential School. School infrastructural facilities form an integral part of the educational system and are an essential factor in quality education.
According to Akande (1985), learning occurs through one's interaction with their environment. Here the environment refers to facilities that are available to develop students' knowledge and their achievement. The environment includes the library, laboratory, Information and Communication Technology (ICT) center, etc., adequately equipped and adequately utilized for efficient and effective learning. Hence the supervisor is interested in undertaking a research study on the availability and utilization of infrastructure in Eklavya Model Residential School. Eklavya Model Residential Schools were initiated and started in India by the

How to cite this article: Biswal, S. and Dansana, A. (2021). Functioning of Eklavya Model Residential School, Rayagada, Odisha. Educational Quest: An Int. J. Edu. Appl. Soc. Sci., 12(2): 73-76.

Source of Support: None; Conflict of Interest: None (ब) क 
Ministry of Tribal Affairs, Government of India, for providing free and high-quality education to meritorious tribal children and this school integrating technologies in the school to enhance the student's Learning Experiences. The Central Board of Secondary Education (CBSE) is affiliating with these schools. In India, there are around 165 Eklavya Model Residential Schools. In Odisha, there are 13 Eklavya Model Residential Schools. In Odisha, it is managed and monitored by the Odisha Model Tribal Education Society (OMTES), supported by SC and ST Development, Govt. of Odisha. These schools have been established in states/ union territories with grants under Article 275(1) of India's constitution.

From the literature review's critical analysis, most of the studies highlighted higher education and school education. But no study was found on tribal school education and particularly in the tribal areas. There is also less research on Eklavya Model Residential School (Mfreke, 2016; Kapur, 2019; Bhunia et al., 2012; Cohen \& Bhatt, 2012; Gibberd, 2007; Olutayo, 2010). So, the researcher is keenly interested in doing a case study on Eklavya Model Residential School. This school provides quality education to merit-based tribal students through developing good infrastructure. Infrastructural facilities work effectively towards the achievement of personal and professional objectives. From the above rationale, the study is entitled "Status of Availability and Utilization of infrastructural facilities in Eklavya Model Residential School: A Case Study."

\section{Research Questions of the Study}

1. What is the status of availability and utilization of infrastructure in Eklavya Model Residential School?

\section{Objectives of the Study}

1. To study the availability and utilization of infrastructure facilities in Eklavya Model Residential School, Rayagad, Odisha.

\section{Methodology of the Study}

Design and Case: The proposed study is a case study that comes under descriptive research. The researcher selected one Eklavya Model Residential School of Rayagada district situated at Rayagada purposively as the case for in-depth analysis. The informants within the study comprised all the teachers 10 (approx.), students 50 (approx.), and the Principal/head.

Tools: With the help of a Checklist, Questionnaire, Interview Schedule, Classroom Observation Schedule, School Observation Schedule, and FGD, the data was obtained from teachers, Head/Principal, and students at Ekalavya Model Residential School. With the assistance of the above tools, the researchers gathered data by maintaining a good relationship.

Data Analysis and Interpretation: Collected data were analyzed using qualitative and quantitative techniques to help the above-stated research tools. The qualitative data analysis included a thick description, content analysis, and quantitative include percentage analysis.

\section{RESULTS}

\section{Profile of the Case}

The Eklavya Model Residential School of Rayagada district, Odisha, was founded in 2000, five kilometers from the bus stand and five kilometers from the railway station. The school was established in a hilly area, and the land area is 14.62 acres. As per the guideline of EMRS, the land area must have 20 acres, but this school didn't match with the policy. In this school, there are 18 teachers and 460 students. The school is affiliated to the Central Board of Secondary Education (CBSE) up to class X. XI and XII affiliated to the Council of Higher Secondary Education, Odisha.

\section{Status}

To seek information regarding the availability and utilization of infrastructural facilities, the investigator interacts with the teachers, principal, students, non-teaching staff. Besides that, thorough observation had been made on the availability and utilization of infrastructural facilities in the school and the hostel.

\section{Academic Facilities}

From the observation, it is revealed that the academic facilities like- Building, classroom, TLM corner, Reading Corner, Play Ground, Boundary Wall, toilet, Safe Drinking Water, library, laboratory, computer lab, Assembly Hall, Lawn/Garden, 
Furniture, Sports Materials, Musical Instruments, etc. were available in the school. The building has the perfect condition. It has two floors: the ground floor and the first floor. The school had a sufficient number of classrooms as per the section. Each class had two sections. There were adequate classrooms. The school wall was covered with many TLM and consisted of good thoughts of great persons inspiring the child. The school has a library. In the library, the Reading corner was available. It was in good condition. The school had two interlinked big playgrounds. In the playground, various games are played by the students like- Kabadi, Volly ball, Badminton, Cricket, Football, KhoKho, Running, High jump and Long jump. The school was demarked by an extensive and height boundary wall in the periphery of the school. The school had required toilet facilities available for boys and girls. The school had Aqua Guard facilities for students as well as for staff. The school had a beautiful garden which is covered with the front of the school. The school had sufficient furniture like- Almirah, Trunk, Chairs and Tables for teachers, Bench, and Desk. This is in good condition. The school provides importance to curricular activities, especially sports. The physical teacher organized various sports likeFootball, Carom, Volleyball, Ring Ball, Badminton, Chess, Ludo, Cricket, KhoKho, Running, high jump, long jump, and long jump and Kabadi.

\section{Residential Facilities}

It is revealed that the residential facilities likeLiving Room; Space in Living Room; Menu for Food; Kitchen Garden; Dining Hall; Furniture in Living Rooms; Electricity and Fan; Toilets; Safe Drinking Water; Recreational Facility; Dispensary; Management and Supervision etc. are available in the school, but there is no Reading Corner is available for the students. The school has two hostels; one is the Boys hostel, and another is Girl's hostel. The hostel has a sufficient no of rooms. In one room, 10-12 students are living. The school hostel has a menu for food. Three times food facility is available that is breakfast, lunch, and dinner. A small kitchen garden is available in the school. The vegetables are growing in this gardentomato, coriander leaves, brinjal, etc. A big dining hall is available in both of the hostels. Furniture is available in the hostel. One bed for each border and also the table and chair are provided to them. A good no of fans and lights are available in the hostel. A good no of toilets is available on each floor of both of the boy's and girl's hostels. Two Acqua Guard is available in the boy's hostel as well as in the Girl's hostel. It is in good condition. The school has organized daily inter-class sports competitions. Various types of plays are collected, which creates happiness among the students. A first-aid facility is available in the school. Medical doctor facilities are available in the school. The warden and matron do not regularly monitor all the borders and maintain discipline in the hostel.

\section{(a) Students Views}

The investigator provided an Information Schedule to students to collect their views about the availability of basic infrastructure of the school as well as a hostel. It is revealed that a high majority of the students (ranging from $76 \%$ to $100 \%$ ) confirmed about the availability as well as the usable condition of the basic infrastructure facilities like spaciousness, neatness of the classroom and hostel room, state of a bench, desk and blackboard in the classroom; connection of power supply, neatness, and cleanness of the toilets, etc. However, the majority of the students (ranging from $60 \%$ to $83 \%)$ stated about the non-availability of some basic infrastructure facilities like power supply, fans and bulbs, and playground. They viewed that "There is a problem with the availability of a drinking water facility in the hostel. Sometimes the amount of food shortage in both school and hostel. The amounts of daily usable items are not provided as per requirement. Sometimes the things like soap, oil, surf are in shortage. All lights and fans are not functioning in the hostel. The doctor comes to check our health once a month. It will be better if the doctor will come every day to the hostel".

\section{CONCLUSION}

The school infrastructure is regarded to be of utmost significance in enabling them to increase the enrolment of students, allow the members to carry out their job duties in an appropriate manner, and achieve the educational goals and objectives. The provision of infrastructural facilities enables individuals to create a friendly and productive working environment. The characteristics of 
infrastructure primarily emphasize how they have proven to be practical and advantageous to individuals. The infrastructure attributes are indispensable, pre-requisites of development, development of skills and abilities, education and personality development, and sustenance of better livelihoods.

\section{REFERENCES}

Bhunia, G.S., Shit, P.K. and Duyari, S. 2012. Assessment of School Infrastructure at Primary and Upper Primary Level: A Geospatial Analysis. Journal of Geographic Information System, 4(5): 412-424.

Cohen, D.K. and Bhatt, M.P. 2012. The Importance of Infrastructure Development to High-Quality Literacy Instruction. The Future of Children, 22(2).

Gibberd, J.T. 2007. Developing a school infrastructure Performance Indicator System (SIPIS). $2^{\text {nd }}$ Built Environment Conference; Association of Schools of Construction of Southern Africa (ASOCSA), Port Elizabeth, South Africa, pp. 12. Retrieved from https:// www.academia.edu/3852700/Developing_a_School_ Infrastructure_Performance_Indicator_System_SIPIS_
Kapur, R. 2019. Infrastructure Development in Schools. Retrieved from https://www.researchgate.net/ publication/334029594_Infrastructure_Development_ in_Schools

Mfreke, U.O. 2016. Teachers' Utilization of School Facilities and Academic Achievement of Student Nurses in Human Biology in Schools of Nursing in Akwalbom State, Nigeria. Journal of Education and Practice, 7(16): 73-80.

Olutayo, A.O. 2010. Education Infrastructure and Unsustainable Development in Africa. Human Affairs, pp. 183-198. Retrieved from file://C:/Users/dell/ Downloads/10.2478_v10023-010-0018-8.pdf 